\title{
Epidemiology of Blackberry chlorotic ringspot virus
}

Bindu Poudel, Thien Ho, Alma Laney, Archana Khadgi, and Ioannis E. Tzanetakis, Department of Plant Pathology, Division of Agriculture, University of Arkansas System, Fayetteville 72701

\begin{abstract}
Poudel, B., Ho, T., Laney, A., Khadgi, A., and Tzanetakis, I. E. 2014. Epidemiology of Blackberry chlorotic ringspot virus. Plant Dis. 98:547-550.

The pollen- and seed-borne ilarviruses pose a substantial threat to many specialty crops, including berries, rose, and tree fruit, because there are no efficient control measures other than avoidance. The case of Blackberry chlorotic ringspot virus (BCRV) is of particular interest because the virus has been found to be an integral part of blackberry yellow vein disease and is widespread in rose plants affected by rose

rosette disease. This study provides insight into the epidemiology of BCRV, including incidence in blackberry and rose; host range, with the addition of apple as a host of the virus; and seed transmission that exceeded $50 \%$ in rose. Sensitive detection protocols that can be used to avoid dissemination of infected material through nurseries and breeding programs were also developed.
\end{abstract}

Blackberry chlorotic ringspot virus (BCRV) belongs to subgroup 1 of the genus Ilarvirus which, along with the genera Alfamovirus, Anulavirus, Bromovirus, Cucumovirus, and Oleavirus, form the family Bromoviridae $(4,6)$. The tripartite genome of the virus consists of a 3.4-kb RNA 1 that codes a single protein with methyltransferase and helicase enzymatic motifs. The 2.8 -kb RNA 2 encodes for the RNA-dependent RNA polymerase and a second open reading frame that encodes a protein believed to be involved in suppression of RNA interference, as inferred from its homology to the $2 \mathrm{~b}$ gene of Asparagus virus-2 (19). The 2.3-kb RNA 3 encodes for the movement and coat proteins of the virus, the latter likely expressed through a subgenomic RNA 4 (22).

Unlike the majority of plant viruses that are dependent on a vector to move between hosts, ilarviruses are efficiently transmitted by seed or pollen $(1,2,5)$. This gives ilarviruses the advantage of vertical as well as horizontal transmission, where the virus is disseminated over large distances through wind currents and pollinating arthropods, as documented for honeybees and Blueberry shock virus (BlShV; 3). Thrips transmission has also been reported in the case of Prune dwarf virus (7), Prunus necrotic ringspot virus, and Strawberry necrotic shock virus (10), possibly facilitating transmission between plant species that would otherwise have not occurred.

Ilarviruses infect several economically important crops in the genera Citrus, Helianthus, Malus, Prunus, Rosa, Rubus, Solanum, and Vaccinium, among others $(5,18,23,25)$. Ilarvirus infection can lead to significant economic damages, as documented for BlShV, causing $100 \%$ yield loss in the Pacific Northwest during the shock reaction period (11), and Tobacco streak virus, causing sunflower necrosis and affecting $80 \%$ of the plants grown in major production areas in India (17). Ilarviruses may also cause significant losses when found in mixed infections with other members of the group or taxonomically distant viruses acting synergistically to cause disease $(12,13,26)$.

Corresponding author: I. E. Tzanetakis, E-mail: itzaneta@uark.edu

* The $\boldsymbol{e}$-Xtra logo stands for "electronic extra" and indicates that Figures 3 and 4 appear in color online.

Current address of B. Poudel: Entomology, Soils, and Plant Sciences, Clemson University, Clemson, SC 29634.

Accepted for publication 2 November 2013.

http://dx.doi.org/10.1094/PDIS-08-13-0866-RE

(C) 2014 The American Phytopathological Society
BCRV was first isolated from blackberry showing line patterns and ringspots in the United Kingdom (9). It was later reported in the United States in rose with rose rosette symptoms, raspberry with mosaic disease, and blackberry exhibiting symptoms of yellow vein disease $(12,21,23)$. In single infections, BCRV induces mild symptoms in tea rose and is asymptomatic in blackberry (14) but may, as reported for other ilarviruses, act synergistically to cause severe disease or exacerbate disease symptoms. This study describes the tools to elucidate BCRV epidemiology, including detection, virus incidence, host range, and seed transmission.

\section{Materials and Methods}

End-point reverse-transcription polymerase chain reaction detection. Nucleic acids were isolated from the area surrounding the primary vein of young, fully matured blackberry and rose leaves and used for reverse-transcription polymerase chain reaction (RT-PCR), as previously described (16). After obtaining information on the complete RNA 3 of 32 isolates (GenBank accessions JX429864 to JX42989; 15), primers were developed to the most conserved regions of the sequenced RNA. Primers BCRV1836F/ BCRV2237R (Table 1) that amplify a 402-base portion of the RNA provided the most reliable results in the pilot studies (data not shown) and were used in duplex PCR reactions with internal control primers NADHF/NADHR (24) to ensure the robustness of the protocol. The thermal cycler (C1000; Bio-Rad) profile for BCRV detection consisted of $1 \mathrm{~min}$ at $94^{\circ} \mathrm{C}$; followed by 40 cycles of $15 \mathrm{~s}$ at $94^{\circ} \mathrm{C}, 15 \mathrm{~s}$ at $55^{\circ} \mathrm{C}$, and $45 \mathrm{~s}$ at $72^{\circ} \mathrm{C}$; followed by $10 \mathrm{~min}$ at $72^{\circ} \mathrm{C}$. The samples were visualized in a $2 \%$ Tris-borate-EDTA

Table 1. Primers and probe used in Blackberry chlorotic ringspot virus (BCRV) detection

\begin{tabular}{ll}
\hline Primer name $^{\mathrm{a}}$ & \multicolumn{1}{c}{ Sequences } \\
\hline Ilarsub1 $^{\mathrm{b}}$ & TTTTTTTTTTTTTTTTGCATCTC \\
BCRV519det1F $^{\mathrm{c}}$ & GTCACACCGAGGTACT \\
BCRV519det1R $^{\mathrm{c}}$ & GTTTCCTGTGCTCCTCA \\
BCRV300det2F & ACTCGAACAATGATAAGCAGCGAT \\
BCRV870det2R & TTAGAAGCAGCGGCATCC \\
BCRV1836F & ACCTGCTGATCAGCTWTCAGAGAA \\
BCRV2237R & TAGAACATCGACCCAAAGGT \\
qPCR BCRV3.298F & AGGTTGAAATGCTTTGACCC \\
qPCR BCRV3.298R & AAGCAGCRCATCGCCTTATAC \\
qPCR BCRV3.298 probe & 6FAM/TCTCGCTGG/Zen/TTCGATGGAG \\
& CT/3IABkFQ \\
\hline
\end{tabular}

${ }^{\mathrm{a}} \mathrm{F}=$ forward, $\mathrm{R}=$ reverse, $\mathrm{qPCR}=$ quantitative polymerase chain reaction.

${ }^{\mathrm{b}}$ Primer used in reverse transcription for subgroup 1 ilarviruses.

${ }^{\mathrm{c}}$ Detection primers used in initial detection.

${ }^{d}$ Universal end-point PCR primers. 
agarose gel stained with GelRed (Biotium). More than 10 amplicons were sequenced and all were found to be virus specific, validating the quality of the protocol.

Quantitative RT-PCR detection. Preparation of RNA, RT, and quantitative (q)PCR design process was performed as previously described (16), with the probe and primer sequences aligned against available BCRV RNA 3 GenBank accessions using ClustalW (20) of the BioEdit package (8). Assays with properties acceptable for qPCR design were evaluated using either nondegenerate or degenerate bases. Primers and probe were synthesized by Integrated DNA Technologies as PrimeTime assays. The probe had a 5' 6-carboxyfluorescein (6-FAM) fluorophore, a ZEN quencher between the 9th and 10th bases, and an Iowa Black FQ quencher at the $3^{\prime}$ end.

qPCR buffer and thermocycling conditions were identical to those previously described (16). Primers with acceptable qPCR parameters were used in end-point PCR reactions to amplify BCRV amplicons used for standard curve construction. Sensitivities of qPCR assays were compared with the end-point PCR protocol described above.

Geographical distribution. The survey was conducted between 2008 and 2011. Blackberry plants from commercial fields and the wild were collected in Arkansas, California, Florida, Georgia, Illinois, Mississippi, North Carolina, South Carolina, and West Virginia whereas rose plants were collected in Alabama, Arkansas, Illinois, Iowa, Missouri, Mississippi, North Carolina, Oklahoma, and Tennessee and tested for the presence of BCRV using the endpoint RT-PCR detection protocol described above.

Host range. At least 16 samples for each of 24 plant species were collected in areas of high BCRV incidence and tested as potential alternate hosts of the virus (Table 2). Plants were sampled from April to September 2010 so as to include early-, mid-, and late-season species. Total nucleic acids were extracted the day of sample collection and end-point RT-PCR detection was performed as described above.

Seed transmission. Seed transmission assays were done on Rosa multiflora naturally infected with BCRV and mechanically inoculated Chenopodium quinoa. For mechanical inoculation, BCRV-infected rose tissue was ground in $0.1 \mathrm{M}$ phosphate buffer $(\mathrm{pH} 7.2)$ containing $2 \%(\mathrm{vol} / \mathrm{vol})$ nicotine at a 1:10 (wt/vol) ratio. Sap was inoculated onto $30 \mathrm{C}$. quinoa seedlings previously dusted with carborundum (600 mesh). Seed were collected from inoculated $C$. quinoa plants that tested positive for BCRV in RT-PCR assays for the seed transmission studies. $R$. multiflora seed were collected and scarified with sulfuric acid $(37 \mathrm{~N})$ for 30 min before sowing. Total nucleic acids were extracted 3 weeks post emergence and tested for the presence of virus by end-point RT-PCR. For each plant species, 100 seedlings were tested to determine the transmission efficiency.

\section{Results}

Detection. More than 20 sets of primers were developed and tested for their robustness and specificity. BCRV1836F/ BCRV2237R (Table 1) was the most efficient primer pair and did not yield amplicons in the negative controls (Fig. 1).

More than 10 TaqMan qPCR probe-primer sets (data not shown), able to detect all available BCRV genotypes, were designed and tested. Nondegenerate sets did not meet the acceptable qPCR quality requirements and, therefore, oligos with degeneracies were evaluated. After considering all parameters, BCRV3.298 assay was selected. The standard curve (eight points) gave an average efficiency $=98.8 \%$, correlation coefficient $=0.999$, slope $=$ -3.352 , and $y$-intercept $=38.736$ (Fig. 2).

The TaqMan qPCR BCRV3.298 assay was compared with the BCRV1836F/BCRV2237R PCR protocol, without the use of the internal control, to determine sensitivity. Using the same serially diluted cDNA on a C1000 Thermal Cycler (Bio-Rad) with five replications, the BCRV3.298 assay could detect BCRV at a 1/4,096 cDNA dilution whereas the BCRV1836F/BCRV2237R counterpart gave visible amplicons at a 1/64 dilution (Fig. 3), making the qPCR protocol at least 64 times more sensitive than its end-point counterpart.

Geographical distribution. In total, 245 blackberry yellow vein disease-affected cultivated and wild blackberry plants were collected from eight states (Table 3) and tested for the presence of BCRV by RT-PCR. The virus was present in all states, including

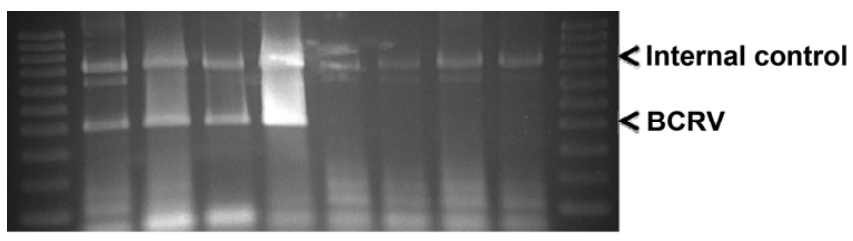

Fig. 1. Agarose gel electrophoresis of Blackberry chlorotic ringspot virus (BCRV) BCRV1835F/BCRV2237R end-point detection polymerase chain reaction. Lanes 1 and 9, 100-bp DNA ladder; lanes 2-5, BCRV-infected material; lanes 6-9, BCRVfree material.

Table 2. Species tested by reverse-transcription polymerase chain reaction as potential alternative hosts for Blackberry chlorotic ringspot virus

\begin{tabular}{|c|c|c|c|}
\hline Plant species & Scientific name & Family & Positive/number tested \\
\hline Amaranthus & Amaranthus spp. & Amaranthaceae & $0 / 16$ \\
\hline Wild garlic & Allium vineale & Amaryllidaceae & $0 / 16$ \\
\hline Dandelion & Taraxacum officinale & Asteraceae & $0 / 16$ \\
\hline Common ragweed & Ambrosia artemisiifolia & Asteraceae & $0 / 16$ \\
\hline Shepherd's purse & Capsella bursa-pastoris & Brassicaceae & $0 / 16$ \\
\hline Nutsedge & Cyperus spp. & Cyperaceae & $0 / 16$ \\
\hline Blueberry & Vaccinium spp. & Ericaceae & $0 / 16$ \\
\hline Garden vetch & Vicia sativa & Fabaceae & $0 / 16$ \\
\hline Red clover & Trifolium pratense & Fabaceae & $0 / 16$ \\
\hline Carolina geranium & Geranium carolinianum & Geraniaceae & $0 / 16$ \\
\hline Carpetweed & Mollugo verticillata & Molluginaceae & $0 / 16$ \\
\hline Creeping woodsorrel & Oxalis corniculata & Oxalidaceae & $0 / 16$ \\
\hline Tall fescue & Festuca arundinacea & Poaceae & $0 / 16$ \\
\hline Wild wheat & Avena fatua & Poaceae & $0 / 16$ \\
\hline Sorghum & Sorghum spp. & Poaceae & $0 / 16$ \\
\hline Curly dock & Rumex crispus & Polygonaceae & $0 / 16$ \\
\hline Peach & Prunus persica & Rosaceae & $0 / 16$ \\
\hline Apple & Malus spp. & Rosaceae & $2 / 200$ \\
\hline Poorjoe & Diodia teres & Rubiaceae & $0 / 16$ \\
\hline Tree of heaven & Ailanthus altissima & Simaroubaceae & $0 / 16$ \\
\hline Horsenettle & Solanum carolinense & Solanaceae & $0 / 16$ \\
\hline Ground cherry & Physalis spp. & Solanaceae & $0 / 16$ \\
\hline Virginia creeper & Parthenocissus quinquefolia & Vitaceae & $0 / 16$ \\
\hline Grape & Vitis vinifera & Vitaceae & $0 / 16$ \\
\hline
\end{tabular}


Illinois and West Virginia, where it had not been documented before. The virus was detected in approximately 4 and $43 \%$ of cultivated and wild blackberry samples, respectively. Survey for the occurrence of BCRV was conducted on 99 randomly collected wild or cultivated rose plants from nine states (Table 3 ). The virus was detected in samples from Arkansas, Missouri, Illinois, and Tennessee om approximately 30 and 58\% of cultivated and wild rose samples, respectively.

Alternative hosts. Apple is a new host for BCRV, with 2 of the 200 trees tested found infected with the virus. Three RNA extrac-

A

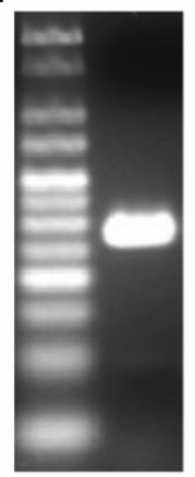

B

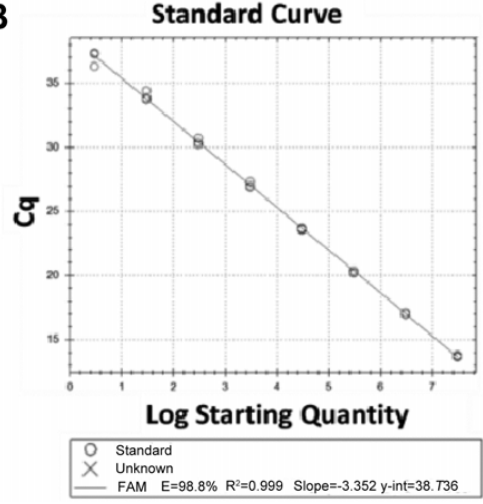

Fig. 2. TaqMan quantitative polymerase chain reaction (qPCR) Blackberry chlorotic ringspot virus BCRV3.298 assay for Blackberry chlorotic ringspot virus (BCRV) detection. A, Agarose gel electrophoresis of a positive qPCR BCRV3.298 product. Lane 1, 25-bp DNA ladder; lane 2, BCRV amplicon. B, Standard curve of BCRV3.298 assay. Circles represent the standards.

A

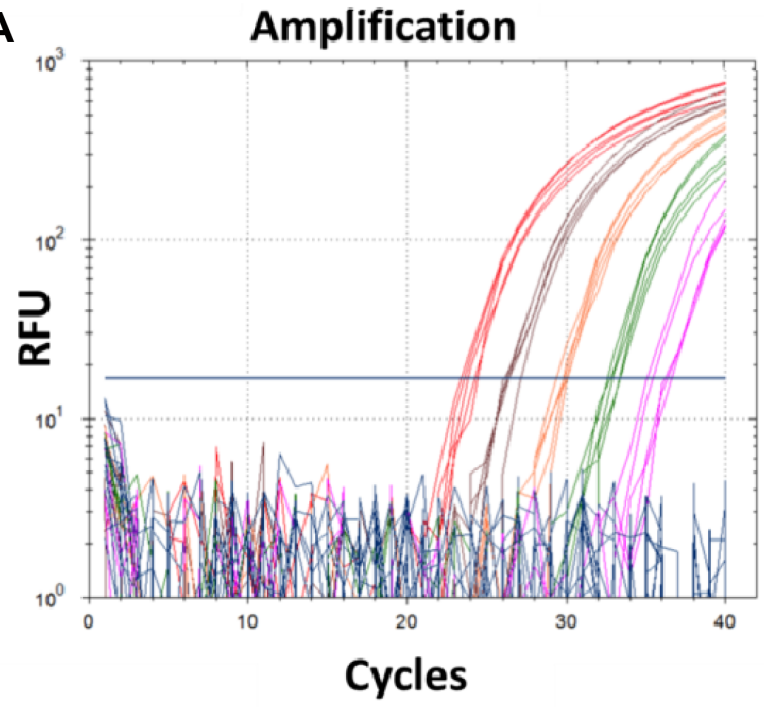

B $\quad \begin{array}{lllllllll}0 & 3 & 6 & 9 & 12 & 15 & 18 & 21 & \text {-ve }\end{array}$

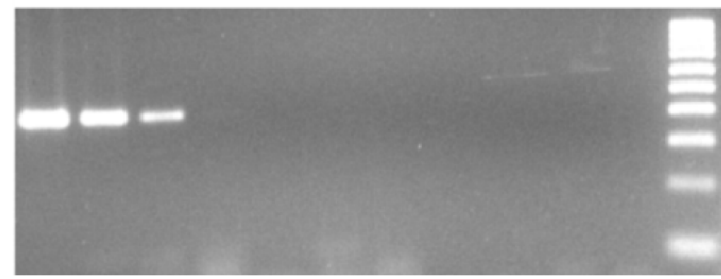

Fig. 3. Detection sensitivity comparison between TaqMan quantitative polymerase chain reaction (qPCR) Blackberry chlorotic ringspot virus BCRV3.298 assay and PCR BCRV1835F/BCRV2237R primer set. A, qPCR graph with five replications. B, Detection PCR gel. Lanes 1-8, BCRV cDNA dilutions; lanes 9 and 10, negative CDNA controls; lane 11, water control. CDNA samples were serially diluted eightfold, corresponding to three PCR cycle equivalents. GPCR BCRV3.298 assay and BCRV1835F/BCRV2237R end-point PCR could detect BCRV at 1/4,096 and 1/64 dilutions, respectively. $\mathrm{RFU}=$ relative fluorescence units. tions followed by RT-PCR reactions were performed to confirm the presence of the virus in those trees. In addition, one sample was sequenced and deposited in GenBank (accession number KF356398). Seed from the same tree were extracted and used to evaluate transmission rate in apple.

Transmission. BCRV was mechanically transmissible to $C$. quinoa; four seedlings developed symptoms and tested positive for the virus (Fig. 4). In all, 49 and $58 \%$ of C. quinoa and R. multiflora seedlings tested for seed transmission, respectively, were infected with the virus. In the case of apple, 3 of 50 seedlings tested positive for BCRV but neither rose nor apple seedlings developed symptoms.

\section{Discussion}

Management of ilarviruses is a challenging undertaking $(13,25)$. Elimination of infected pollen is unfeasible and the best approach to minimize ilarvirus impact is to grow crops in virus-free areas, using certified material, tested for the viruses of interest (26). BCRV is a virus of particular concern because it infects at least four important rosaceous species. Although BCRV does not cause detrimental symptoms in single infections in the species tested

Table 3. Geographic distribution of Blackberry chlorotic ringspot virus in blackberry and rose showing virus-like symptoms ${ }^{\mathrm{a}}$

\begin{tabular}{|c|c|c|c|c|}
\hline \multirow[b]{2}{*}{ Plant, year } & \multirow[b]{2}{*}{ State } & \multicolumn{3}{|c|}{ Number of plants (positive/tested) } \\
\hline & & Cultivated & Wild & Total \\
\hline \multicolumn{5}{|l|}{ Blackberry } \\
\hline 2008 & Arkansas & $1 / 31$ & $0 / 7$ & $1 / 31$ \\
\hline 2008 & Georgia & $0 / 24$ & - & $0 / 24$ \\
\hline 2008 & North Carolina & $0 / 4$ & - & $0 / 4$ \\
\hline 2009 & Arkansas & $0 / 2$ & - & $0 / 2$ \\
\hline 2009 & North Carolina & $1 / 36$ & - & $1 / 36$ \\
\hline 2009 & South Carolina & $1 / 22$ & - & $1 / 22$ \\
\hline 2010 & Arkansas & - & $26 / 66$ & $26 / 66$ \\
\hline 2010 & Illinois & - & $7 / 7$ & $7 / 7$ \\
\hline 2010 & West Virginia & - & $3 / 9$ & $3 / 9$ \\
\hline 2011 & Florida & $1 / 25$ & - & $1 / 25$ \\
\hline 2011 & Georgia & $3 / 19$ & - & $3 / 19$ \\
\hline Total & $\ldots$ & $7 / 163$ & $36 / 82$ & $43 / 245$ \\
\hline \multicolumn{5}{|l|}{ Rose } \\
\hline 2009 & Alabama & $0 / 5$ & - & $0 / 5$ \\
\hline 2009 & Arkansas & - & $23 / 31$ & $23 / 31$ \\
\hline 2009 & Iowa & - & $0 / 9$ & $0 / 9$ \\
\hline 2009 & Illinois & - & $5 / 5$ & $5 / 5$ \\
\hline 2009 & Missouri & - & $10 / 10$ & $10 / 10$ \\
\hline 2009 & North Carolina & $0 / 10$ & - & $0 / 10$ \\
\hline 2009 & Oklahoma & - & $0 / 10$ & $0 / 10$ \\
\hline 2009 & Tennessee & $9 / 11$ & - & $9 / 11$ \\
\hline 2010 & Missouri & - & $3 / 5$ & $3 / 5$ \\
\hline 2010 & Mississippi & $0 / 3$ & - & $0 / 3$ \\
\hline Total & $\ldots$ & $9 / 29$ & $41 / 70$ & $45 / 99$ \\
\hline
\end{tabular}

a - Indicates lack of data for that particular year-state combination.
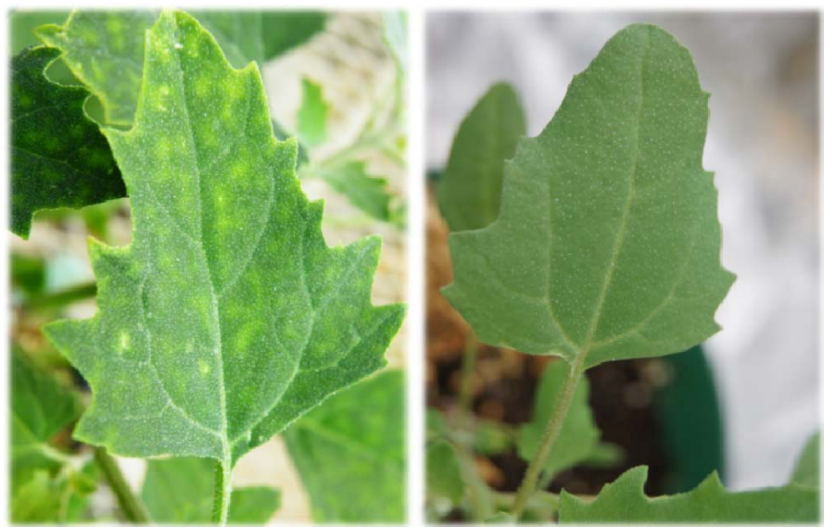

Fig. 4. Symptoms of Blackberry chlorotic ringspot virus (BCRV) on Chenopodium quinoa. Left: BCRV-infected material and right: mock-inoculated plant. 
(14), its presence in plants with raspberry mosaic and blackberry yellow vein diseases $(15,23)$ suggests that BCRV may be one of the contributing factors for disease development. This study focused on several aspects of virus epidemiology: detection, incidence, host range, and transmission. Detection is a mandatory step in disease management; however, when working with a newly identified pathogen, it is critical to obtain sufficient information on its population structure to ensure robust and reliable detection. The end-point and quantitative PCR protocols, developed based on the population structure of the virus in the United States (15), are able to amplify all sequenced isolates and will reduce the chance of false negatives, being of greater utility to certification and quarantine programs.

The presence of the virus was verified in most states that were surveyed. BCRV was also detected in a high percentage of wild plants that may serve as an inoculum source for nearby agricultural plantings. This must be considered when developing management strategies. Apple was confirmed as a host of the virus, indicating that BCRV might have a wider host range among rosaceous hosts. Although this communication provides data that can be used to minimize virus spread, additional work is needed to fill in knowledge gaps. Alternative hosts play an important role in epidemiology by acting as virus reservoirs, and the detection of BCRV in apple signifies the importance of vigorous testing of species that can potentially be hosts for the virus. Additionally, several ilarviruses have been shown to be transmitted with pollen-bearing arthropods $(3,7,10)$, which could provide a transmission route across species, though this remains to be tested for BCRV. Breeders need to be aware that BCRV appears to be seed transmitted at high rates.

\section{Literature Cited}

1. Amari, K., Burgos, L., Pallas, V., and Sanchez-Pina, M. A. 2009. Vertical transmission of Prunus necrotic virus: hitch-hiking from gametes to seedlings. J. Gen. Virol. 90:1767-1774.

2. Aparicio, F., Sanchez-Pina, M. A., Sanches-Navarro, J. A., and Pallas, V. 1999. Location of Prunus necrotic ringspot ilarvirus within pollen grains of infected nectarine trees: evidence form RT-PCR, dot-blot and in-situ hybridization. Eur. Plant Pathol. 105:623-627.

3. Bristow, P. R., and Martin, R. R. 1999. Transmission and the role of honeybees in field spread of Blueberry shock ilarvirus, a pollen-borne virus of high bush blueberry. Phytopathology 89:124-130.

4. Bujarski, J., Figlerowicz, M., Gallitelli, D., Roossinck, M. J., and Scott. S. W. 2011. Family Bromoviridae. Pages 965-976 in: Virus Taxonomy: Ninth Rep. Int. Committee Taxonomy Viruses. A. M. Q. King, M. J. Adams, E. B. Carstens, E. J. Lefkowitz, eds. Elsevier/Academic Press, San Diego.

5. Card, S. D., Pearson, M. N., and Clover, G. R. C. 2007. Plant pathogens transmitted by pollen. Plant Pathol. 36:455-461.

6. Carstens, E. B., and Ball, L. A. 2009. Ratification vote on taxonomic proposals to the International Committee on Taxonomy of Viruses (2008). Arch. Virol. 154:1181-1188.

7. Greber, R. S., Teakle, D. S., and Mink, G. I. 1992. Thrips facilitated transmission of prune dwarf and Prunus necrotic ringspot viruses from cherry pollen to cucumber. Plant Dis. 76:1039-1041.
8. Hall, T. A. 1999. BioEdit: a user-friendly biological sequence alignmen editor and analysis program for Windows 95/98/NT. Nucleic Acids Symp. Ser. 41:95-98.

9. Jones, A. T., McGavin, W. J., Gepp, V., Zimmerman, M. T., and Scott, S. W. 2006. Purification and properties of Blackberry chlorotic ringspot, a new virus species in subgroup 1 of the genus Ilarvirus found naturally infecting blackberry in UK. Ann. Appl. Biol. 149:125-135.

10. Kaiser, W. J., Wyatt, S. D., and Pesho, G. R. 1982. Natural hosts and vectors of Tobacco streak virus in eastern Washington. Phytopathology 72:1508-1512.

11. MacDonald, S. G., Martin, R. R., and Bristow, P. R. 1991. Characterization of an ilarvirus associated with a necrotic shock reaction in blueberry. Phytopathology 81:210-214.

12. Martin, R. R., MacFarlane, S., Sabanadzovic, S., Quito, D., Poudel, B., and Tzanetakis, I. E. 2013. Viruses and virus diseases of Rubus. Plant Dis. 97:169-182.

13. Pallas, V., Aparicio, F., Herranz, M. C., Amari, K., Sanchez-Pina, M. A., Myrta, A., and Sanchez-Navarro, J. A. 2012. Ilarviruses of Prunus spp.: a continued concern for fruit trees. Phytopathology 102:1108-1120.

14. Poudel, B. 2011. Epidemiological studies on Blackberry yellow vein associated virus and Blackberry chlorotic ringspot virus. M.S. thesis, University of Arkansas, Fayetteville.

15. Poudel, B., and Tzanetakis, I. E. 2013. Population structure of Blackberry chlorotic ringspot virus. Arch. Virol. 158:667-672.

16. Poudel, B., Wintermantel, W. M., Cortez, A. A., Ho, T., Khadgi, A., and Tzanetakis, I. E. 2013. Epidemiology of Blackberry yellow vein associated virus. Plant Dis. 97:1352-1357.

17. Ramaiah, M., Bhat, A. I., Jain, R. K., Pant, R. P., Ahlawat, Y. S., Prabhakar, K., and Varma, A. 2001. Isolation of an isometric virus causing sunflower necrosis disease in India. Plant Dis. 85:443

18. Saade, M., Aparicio, F., Sanchez-Navarrro, J. A., Herranz, M. C., Myrta, A., Di-Terlizzi, B., and Pallas, V. 2000. Simultaneous detection of the three ilarviruses affecting stone fruit trees by non-isotopic molecular hybridization and multiplex reverse transcription-polymerase chain reaction. Phytopathology 90:1130-1136.

19. Shimura, H., Masuta, C., Yoshida, N., and Sueda, K. 2013. The 2b protein of Asparagus virus 2 functions as an RNA silencing suppressor against systemic silencing to prove functional synteny with related cucumoviruses. Virology 442:180-188.

20. Thompson, J. D., Higgins, D. G., and Gibson, T. J. 1994. CLUSTALW: improving the sensitivity of progressive multiple sequence alignment through sequence weighting, position-specific gap penalties and weight matrix choice. Nucleic Acids Res. 22:4673-4680.

21. Tzanetakis, I. E., Gergerich, R. C., and Martin, R. R. 2006. A new ilarvirus found in rose. Plant Pathol. 55:568.

22. Tzanetakis, I. E, Martin, R. R., and Scott, S. W. 2010. Genomic sequences of Blackberry chlorotic ringspot virus and Strawberry necrotic shock virus and the phylogeny of viruses in subgroup 1 of the genus Ilarvirus. Arch. Virol. 155:557-561.

23. Tzanetakis, I. E., Postman, P. D., and Martin, R. R. 2007. First report of Blackberry chlorotic ringspot virus in Rubus sp. in the United States. Plant Dis. 91:463.

24. Tzanetakis, I. E., Postman, P. D., and Martin, R. R. 2007. Identification, detection and transmission of a new Vitivirus from Mentha. Arch. Virol. 152:2027-2033.

25. Uyemoto, J. K., Asai, W. K., and Luhn, C. F. 1992. Ilarviruses: evidence for rapid spread and effects on vegetative growth and fruit yields in peach trees. Plant Dis. 76:71-74.

26. Uyemoto, J. K., and Scott, S. W. 1992. Important disease of Prunus caused by viruses and other graft-transmissible pathogens in California and South Carolina. Plant Dis. 76:5-11. 